\title{
Chromatographic Fingerprint analysis for Determining the Presence of Vitexin and Isovitexin on Seven Varieties of Ficus Deltoidea
}

\author{
Zunoliza Abdullah*1, Nor Azah Mohamad Ali², Mailina Jamil'2, Nashriyah Mat ${ }^{3}$, \\ Abdul Manaf Ali ${ }^{3}$, Nurul Aina Awang ${ }^{3}$, Wan Ainor Syahdah Wan Hassan ${ }^{3}$, \\ Ling Sui Kiong ${ }^{1}$, Mohd Hafidz Hadi Abdullah ${ }^{1}$, \\ Nor Azlianie Ab'llah@Awang ${ }^{1}$, Norfaizura Azmi ${ }^{3}$
}

\author{
${ }^{1}$ Phytochemistry Programme, Natural Products Division, \\ Forest Research Institute Malaysia (FRIM), 52109 Kepong, Selangor, Malaysia. \\ ${ }^{2}$ Herbal Product Development Programme, Natural Products Division, \\ Forest Research Institute Malaysia (FRIM), 52109 Kepong, Selangor, Malaysia \\ ${ }^{3}$ School of Agriculture Science and Biotechnology, Faculty of Bioresource and Food Industry, \\ Universiti Sultan Zainal Abidin, Tembila Campus, Terengganu, Malaysia \\ *Corresponding author: zunoliza@frim.gov.my
}

\begin{abstract}
Ficus deltoidea Jack or locally known as mas cotek from the family of Moraceae has been acknowledged for its occurrence of several varieties based on the variations of leaf morphology, namely F. deltoidea var. angustifolia (Miq.) Corner, F. deltoidea var. bilobata Corner, F. deltoidea var. kunstleri (King) Corner, F. deltoidea var. lutescens (Desf.) Corner, F. deltoidea var. trengganuensis Corner, $F$. deltoidea var. motleyana and F. deltoidea var. deltoidea Jack. In this work, we report on the chemical profiles using chromatographic techniques on the seven varieties of $F$. deltoidea by analysing the presence of the bioactive compounds, vitexin and isovitexin and characterising the other major peaks in the chromatograms. Observation on the HPLC chromatogram showed the presence of both compounds in all samples except FDv. K (vitexin only) and FDv. I. Other peaks showed a characteristic of flavonoids based on the UV spectra pattern with UV maxima at 270 and $338 \mathrm{~nm}$ except for peaks 6, 7 and 8 with UV maxima at 294, 319 and 210, respectively. Both reference compounds were presence in varies concentration in all samples analysed.
\end{abstract}

Keywords: Ficus deltoidea; chromatographic analysis

\section{INTRODUCTION}

The usage of herbal based products has increased globally especially for complementary and alternative medicines. The expenditure on the traditional and herbal medicinal products has increased tremendously from $\$ 20$ billion in 1997 to US\$83 billion in 2008 [1-3]. Besides its lower price as compared to the modern drugs, the natural occurrence and the consumption from generation to generation are also the main reason as to why the herbal medicines and herbal based products have become more acceptable to the consumers [4]. Herbal medicines are usually herbal based products that contain the whole plants, parts of the plants or combination of the parts or plants either from raw material or in the extracted form. Some of them may contain sources of animal parts and/or minerals [5]. Various processing methods and combinations of the herbal materials have been used to maximize the therapeutic efficiency and minimize the toxicity of the herbal medicinal products [3, 6-9].

Despite the availability of many traditional/herbal medicinal products, the authenticity, quality, safety and efficacy studies on these herbal medicines remain a major thrust area in the research activities because the drug alteration and misidentification of herbal plants is still a major problem faced by the 
herbal industry. Misidentification of herbal ingredients due to their different names resulted in consumption of wrong herbal medicines which may lead to unexpected effects. According to Kochummen [10] and Turner [11] as cited by A. Nasir et al [12] there are seven varieties of Ficus deltoidea (FD) has been recognised in Peninsular Malaysia namely FD var. deltoidea, var. angustifolia, var. trengganuensis, var. bilobata, var. intermedia, var. kunsleri and var. motleyana. Despite of myriad herbal products containing FD as one of the ingredients, the identity of varieties that has been used in the preparation has always been query. The correct identification of varieties is important in maintaining the quality of products. Therefore, the present study has been conducted to develop an analytical technique that can be used in the identification and authentication of FD varieties.

The identification and authentication of the herbal plants are usually carried out by studying the botanical anatomy and phytochemical profiles. Analytically, the secondary metabolites such as carotenoids/chlorophylls/phenolic acids/flavonoids/alkaloids/antocyanins/terpenoids and phytosterols have been used as markers or reference compounds in the identification and authentication. These phytochemicals have played important roles in either the attraction or defence mechanism. Polyphenols and its derivatives are the most important secondary metabolites found in medicinal plants which have shown wide ranges of beneficial effects such as antibacterial, anticarcinogenic, anti-inflammatory, antiviral, antiallergic, estrogenic and immune-stimulating properties [13].

The fingerprint analysis that evaluates the integrative and holistic properties of herbal medicines has been acceptable internationally as one of the efficient methods in quality control of herbal medicines [14]. The Food and Drug Administration, FDA [15] and European Medicines Agency, EMEA [16] have denoted the application of appropriate fingerprint chromatogram in determining the consistency of botanical drugs. Several analytical techniques have been applied in the determination of the quality of herbal plants. One of the techniques, namely chromatographic fingerprinting is the most powerful approach $[4,17]$ in the development of phytochemical profile that will provide information on the appearance of peaks that feature the similarity or dissimilarity between various samples of herbal plants that are used in the preparation of herbal medicines. Chromatographic fingerprinting can be carried out using techniques such as thin layer chromatography (TLC), high performance liquid chromatography (HPLC), gas chromatography (GC) and other hyphenated techniques.

Ficus deltoidea or locally known as mas cotek from the family of Moraceae is one of the most popular herbal plants that has been used among the Malays. This plant is traditionally being used for treating wounds, rheumatism and sores. A decoction of the leaves is also used by women after giving birth to improve blood circulation and regain body strength. Some ethnic groups in East Malaysia consume the plant as herbal tea for anti-aging and young appearance. Several biological studies have been reported on this plant which included antioxidants [18-22], antihypertensive [23-24], anti-diabetic [25-30], anti-inflammatory [20,31], antimelanogenic and antiphoto-aging effect [32-33], antiulcerogenic [34], wound healing [35], antibacterial [36-37] and anticancer [38]. Acute and subchronic toxicity study by Farsi et al [39] showed that there were no significant adverse effects of toxicity symptom on the Sprague Dawley rats.

Research also showed that $F$. deltoidea possesses five active components which are required by the human body, namely flavanoids, tannins, triterpenoids, proanthocyanins and phenols [20,32]. Omar et al [22] reported the presence of antioxidant flavonoids including flavan-3-ol monomers namely; catechin, epicatechin, gallocatechin and epigallocatechin in the aqueous extracts. A few chemical compounds have been found present in the leaves of $F$. deltoidea which included prangenin, 3,5-ditertbutylphenol, methyl 3-(3,5-ditertbutyl-4-hydroxyphenyl, vitexin, isovitexin and moretenol [20, 25, 40]. Two of the compounds, namely vitexin and isovitexin have been reported to play a role as an antidiabetic agent through in-vivo $\alpha$-glucosidase inhibition [41]. Both of these compounds have been used as the reference marker for the chemical profiling of three varieties of Ficus deltoidea leaves or its extracts [20]. There were several articles reporting on the pharmacological activities of these compounds such as antihypertensive, anti-inflammatory, antispasmodic, antimicrobial and antioxidant [42-44]. 
In this study we have utilized both of the compounds; vitexin and isovitexin as reference markers for chromatographic fingerprint analysis on seven varieties of Ficus deltoidea that are available in the Peninsular of Malaysia. The analysis also included the characterization of the other major peaks in the chromatograms.

\section{EXPERIMENTAL}

\section{Plant materials and chemicals}

The leaves of all the seven varieties of Ficus deltoidea were harvested from the germplasm plot at Universiti Sultan Zainal Abidin (Unisza) located at Besut, Terengganu. The samples are listed in Table 1. Vitexin and isovitexin were used as the reference compounds. HPLC grade acetonitrile and water were used for the HPLC analysis.

Table 1 List of varieties of Ficus deltoidea leaves

\begin{tabular}{|c|l|c|c|}
\hline No. & Samples & Code & $\begin{array}{c}\text { Herbarium } \\
\text { No. }\end{array}$ \\
\hline 1 & Ficus deltoidea var motleyana & FDv. M & 00313 \\
\hline 2 & Ficus deltoidea var bilobata & FDv. B & 00057 \\
\hline 3 & Ficus deltoidea var intermedia & FDv. I & 00308 \\
\hline 4 & Ficus deltoidea var kunstleri & FDv. K & 00312 \\
\hline 5 & Ficus deltoidea var deltoidea & FDv. D & 00367 \\
\hline 6 & Ficus deltoidea var terengganuensis & FDv. T & 00300 \\
\hline 7 & Ficus deltoidea var angustifolia & FDv. A & 00331 \\
\hline
\end{tabular}

\section{Preparation of samples}

Dried and ground samples were extracted using methanol at room temperature with a ratio of $1 \mathrm{~g}: 10$ $\mathrm{mL}$. The extracts were filtered and then dried in vacuo at $40^{\circ} \mathrm{C} .40 \mathrm{mg}$ of each sample was taken and re-dissolved in $1 \mathrm{~mL}$ of methanol (HPLC grade) for the analysis. Formic acid was of analytical grade.

\section{Preparation of standard and extract solution}

Standard stock solution of vitexin and isovitexin were prepared at a concentration of $1 \mathrm{mg} / \mathrm{mL}$ in methanol. The solution was filtered through $0.45 \mu \mathrm{m}$ PTFE membrane filter.

\section{Instrumentation and chromatographic conditions}

HPLC analysis was performed on WATERS 600E pump attached with 2996 photodiode array detector and data were analysed using Empower software. The analysis was carried out on a reversed phase column, Purospher® STAR $(250$ x $4.6 \mathrm{~mm}, 5 \mu \mathrm{m})$. The solvent system consisted of $0.1 \%$ formic acid in water (A) and acetonitrile (B) with a linear gradient elution developed over 45 minutes running time. The flow rate was set at $1 \mathrm{~mL} / \mathrm{min}$ and the injection volume was $10 \mathrm{uL}$.

\section{RESULTS AND DISCUSSION}

Studies conducted by several researchers $[20,22,25,40]$ have reported the presence of a few types of chemical components in Ficus deltoidea which included catechin, epicatechin, gallocatechin and epigallocatechin, prangenin, 3,5-di-tertbutylphenol, methyl 3-(3,5-ditertbutyl-4-hydroxyphenyl, vitexin, isovitexin and moretenol. However, in the present study, only vitexin and isovitexin were used as the 
reference markers due to its role as antidiabetic agent in in vivo $\alpha$-glucosidase inhibition as reported by Choo et al [41]. The potential inhibition of these compounds on $\alpha$-glucosidase activity also been reported by Yao et al [45]. The chromatographic profile has been optimized using different types of columns with different combinations of mobile phase. Satisfactory chromatographic profile was obtained after using the reversed phase column, Purospher ${ }^{\circledR}$ STAR with gradient elution for $45 \mathrm{~min}$. Both compounds showed maximum absorptions $\left(\lambda_{\max }\right)$ at $270 \mathrm{~nm}$ and $330 \mathrm{~nm}$. The chromatograms and UV spectra of vitexin (1) and isovitexin (2) extracted at $270 \mathrm{~nm}$ are shown in Figure 1. They were eluted at retention times $26.136 \mathrm{~min}$ and $27.227 \mathrm{~min}$, respectively. Figure 2 displayed the chromatograms and UV spectra of the major peaks observed in all the seven varieties of Ficus deltoidea leaves. The presence of both compounds; vitexin and isovitexin were observed and labelled as peak 9 and 10, respectively by the comparison of their retention times and UV spectra. Figure 2 also showed the presence of other peaks which exhibited similar UV spectral characteristics of vitexin and isovitexin, an apigenin flavone glucoside. Besides that, the HPLC chromatogram also exhibited three other peaks with different pattern from the vitexin and isovitexin labelled as peak 6,7 and 8 with UV maxima at $294 \mathrm{~nm}, 319 \mathrm{~nm}$ and 310 $\mathrm{nm}$, respectively. As observed in the chromatograms, both vitexin and isovitexin can be found in all varieties of Ficus deltoidea (Ficus deltoidea var motleyana, Ficus deltoidea var bilobata, Ficus deltoidea var deltoidea, Ficus deltoidea var terengganuensis and Ficus deltoidea var angustifloia) except in Ficus deltoidea var intermedia and Ficus deltoidea var kunstleri. Table 2 exhibited the concentration of vitexin and isovitexin calculated in five varieties of Ficus deltoidea. As calculated from the linear plot of vitexin $\left(\mathrm{R}^{2}=0.9999\right)$ and isovitexin $\left(\mathrm{R}^{2}=0.9996\right)$, FDv. B showed the highest concentration of vitexin with $298.28 \pm 3.97 \mu \mathrm{g} / \mathrm{mL}$, while the FDv. A showed the highest concentration of isovitexin with $184.50 \pm 0.35 \mu \mathrm{g} / \mathrm{mL}$.<smiles>O=c1cc(-c2ccc(O)cc2)oc2c(C3O[C@H](CO)C(O)C(O)C3O)c(O)cc(O)c12</smiles>

Vitexin (1)<smiles>O=c1cc(-c2ccc(O)cc2)oc2cc(O)c([C+]3O[C@H]([CH+]CO)[C@@H](O)C(O)[C@H]3O)c(O)c12</smiles>

Isovitexin (2)
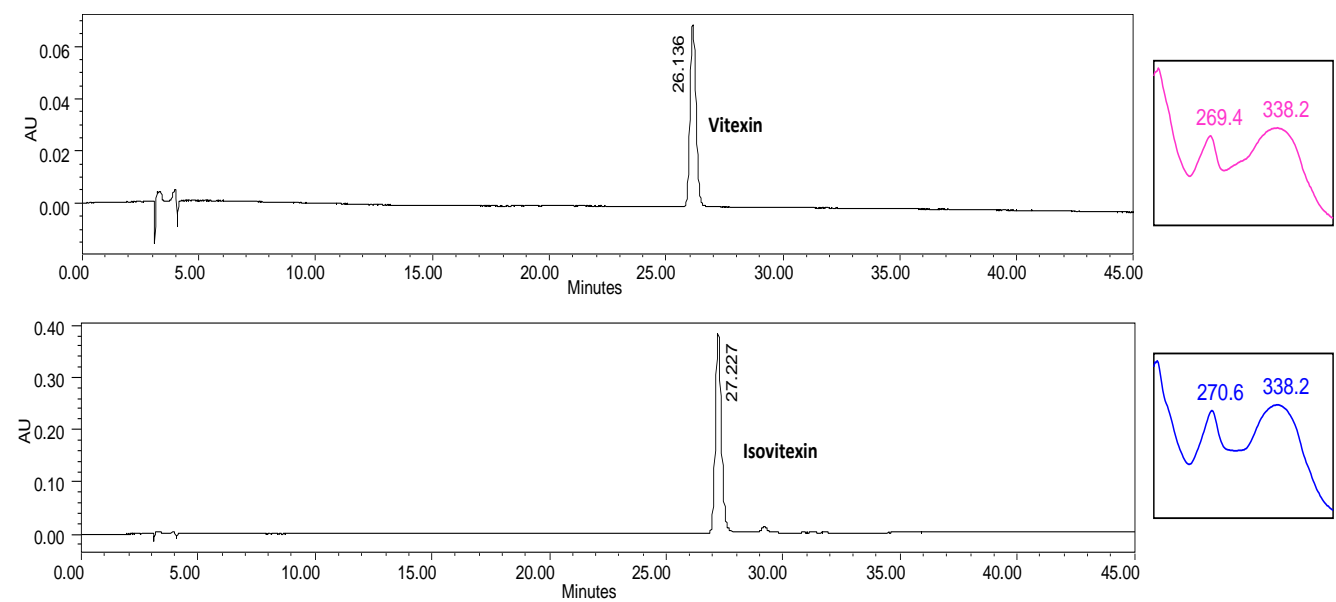

Figure 1: HPLC chromatogram of vitexin and isovitexin at $270 \mathrm{~nm}$ 
Chromatographic Fingerprint analysis for Determining the Presence of Vitexin and Isovitexin on Seven Varieties of Ficus Deltoidea
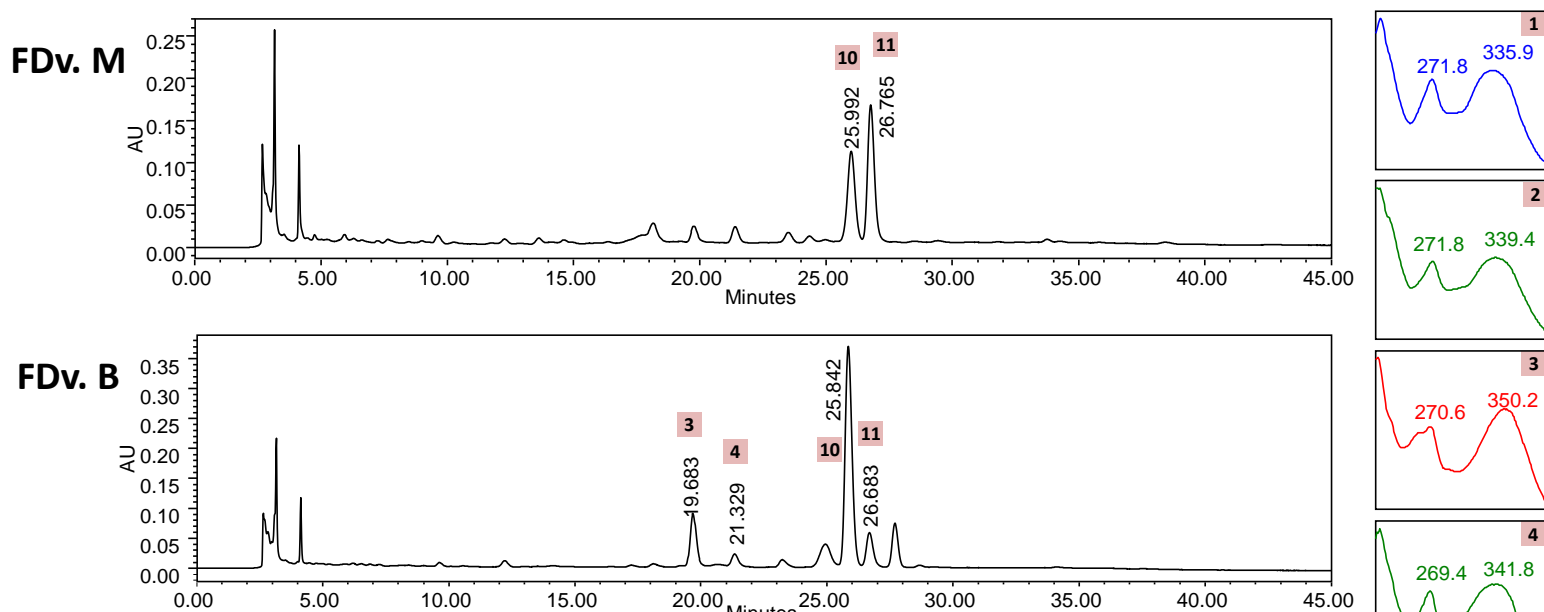

FDv. B
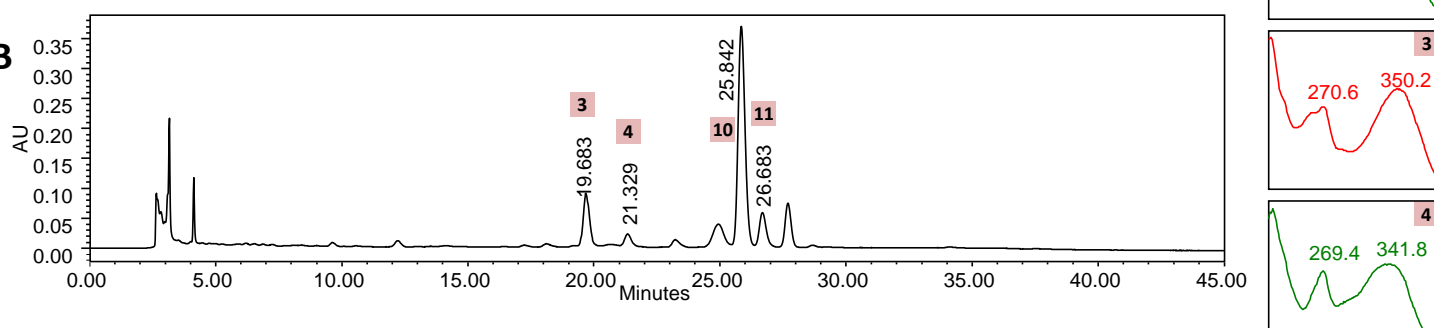

FDv. 1
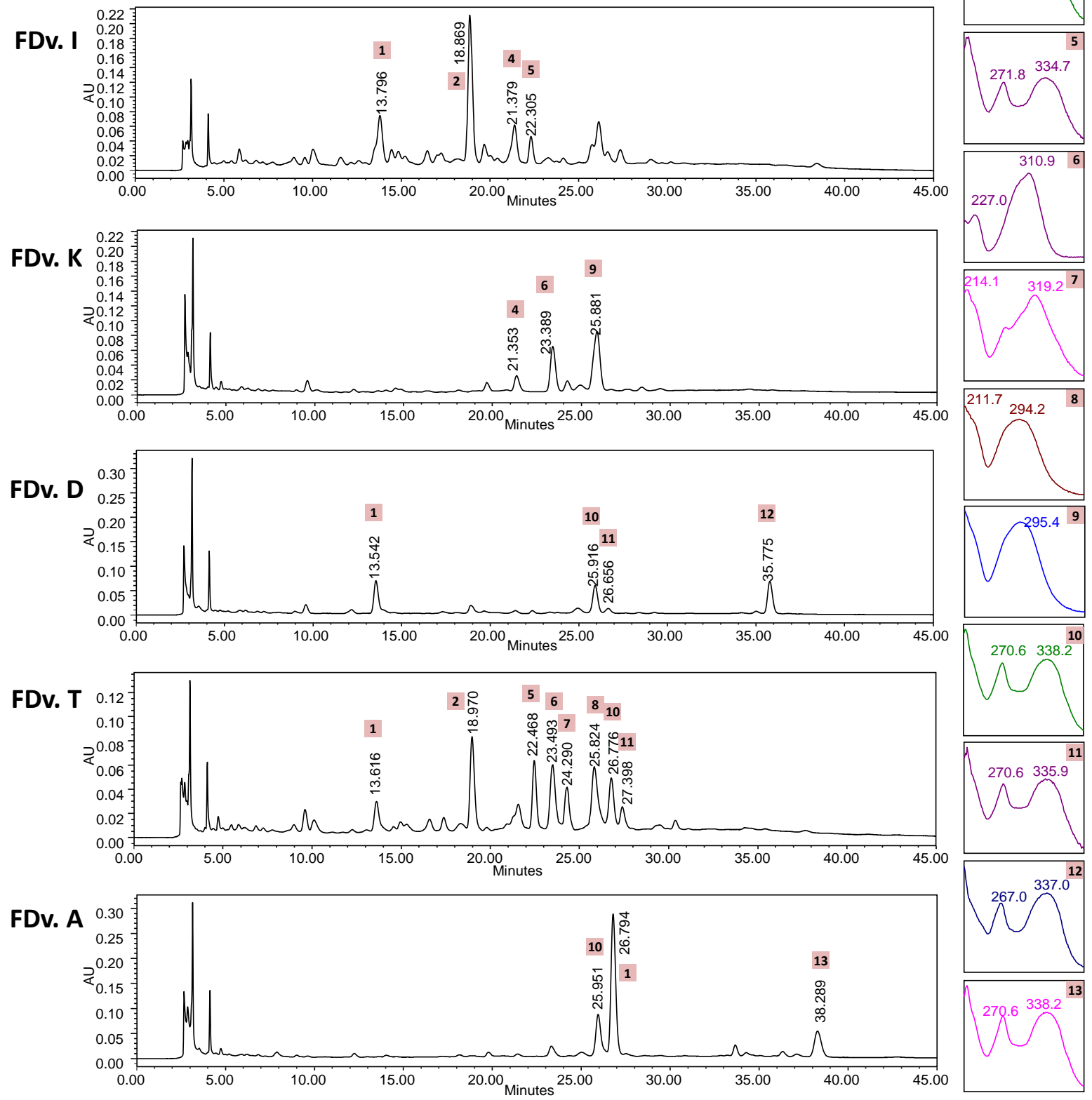

Figure 2 HPLC chromatogram and UV spectra of seven varieties of Ficus deltoidea at $270 \mathrm{~nm}$ 
Chromatographic Fingerprint analysis for Determining the Presence of Vitexin and Isovitexin on Seven Varieties of Ficus Deltoidea

Table 2 Retention time and calculated concentration of vitexin and isovitexin in five varieties of Ficus deltoidea

\begin{tabular}{|c|c|c|c|c|}
\hline \multirow{2}{*}{ Sample code } & \multicolumn{2}{|c|}{ Vitexin } & \multicolumn{2}{c|}{ Isovitexin } \\
\cline { 2 - 5 } & RT $(\min \pm \mathrm{SD})$ & $\begin{array}{c}\text { Concentration } \pm \mathrm{SD} \\
(\mu \mathrm{g} / \mathrm{mL})\end{array}$ & RT $(\mathrm{min} \pm \mathrm{SD})$ & $\begin{array}{c}\text { Cconcentration } \pm \text { SD } \\
(\mu \mathrm{g} / \mathrm{mL})\end{array}$ \\
\hline FDv.M & $25.99 \pm 0.02$ & $94.68 \pm 0.22$ & $26.78 \pm 0.03$ & $106.32 \pm 0.87$ \\
\hline FDv.B & $25.82 \pm 0.03$ & $298.28 \pm 3.97$ & $26.66 \pm 0.04$ & $33.54 \pm 0.97$ \\
\hline FDv.D & $25.96 \pm 0.03$ & $46.29 \pm 0.70$ & $26.69 \pm 0.03$ & $3.26 \pm 0.42$ \\
\hline FDv.T & $26.78 \pm 0.02$ & $28.77 \pm 0.62$ & $27.40 \pm 0.02$ & $7.12 \pm 0.43$ \\
\hline FDv.A & $25.94 \pm 0.04$ & $64.01 \pm 1.52$ & $26.77 \pm 0.04$ & $184.50 \pm 0.35$ \\
\hline
\end{tabular}

Values are means \pm standard deviation

\section{CONCLUSION}

A HPLC method for chromatographic fingerprint analysis using vitexin and isovitexin as the reference compounds for Ficus deltoidea has been successfully developed. The developed method also showed the presence of other compounds that showed similar UV spectra with the reference compounds. The chromatograms also exhibited the presence of peaks belonging to other types of compounds such as the phenolics. These chromatographic fingerprints and method developed could be employed as one of the analytical methods in the quality control and authentication of raw materials of Ficus deltoidea. The concentration of vitexin and isovitexin varies in all five varieties that showed the presence of both reference compounds. The highest concentration of vitexin and isovitexin was calculated in Ficus deltoidea var. bilobata and Ficus deltoidea var. angustifolia, respectively.

\section{REFERENCES}

[1] World Health Organization (2011) The World Medicine Situation. Traditional Medicines: global situations, issues and challenges.

[2] Khan, I. A. (2006) Issues Related to Botanicals. Life Sciences, 78(18), 2033-2038.

[3] Wah, C.L., Hock, S. C. \& Yun, T.K. (2012) Current Scientific status and regulatory control of traditional/Herbal Medicinal Prodcuts: Globalization Challlenges, Pharmaceutical Engineering, magazine of ISPE, November/December 2012, 32(6), www.PharmaceuticalEngineering.org

[4] Kaushik , D., Pandey, M. K. \& Sharma, A. (2014) Current issue in authentication and quality control of natural products, Research in plant Biology, 4(5), 57-64.

[5] WHO Traditional Medicine Strategy 2002-2005. Geneva, World Health Organization, 2002 (WHO/EDM/TRM/2001.1).

[6] Zhao, F. R., Mao, H. P, Zhang, H., et al., Antagonistic effects of two herbs in Zuojin Wan, a traditional chinese medicines formula, on catecholamine secretion in bovine adrenal medullary cells, Phytomedicine, 17(8-9), , pp. 659-668,2010(a).

[7] Yang, W. J., Li, D. P., Li, J. K., et al. (2009) Synergistic Antioxidant activities of eight traditional chinese herb pairs, Biological and Pharmaceutical Bulletin, 32(6), 1021-1026.

[8] Ung, C. Y., Li, H., Cao, Z. W., et al. (2007) Are Herb-Pairs of Traditional Medicine Distinguishable from the others? Pattern analysis and artificial intelligence properties, Journal of Ethnopharmacology, 111(2), 371-377.

[9] Zhao,Z., Liang, Z., Chan, K., et al. Unique Issue in the Standardization of Chinese Materia medica: Processing, Planta Med, 76(17), ,pp. 1975-198, 2010(b).

[10] Kochummen, K. M., \& Rusea, G. (2000). Tree Flora of Sabah and Sarawak (Vol. 3, pp. 181-334).

[11] Turner, I. M. (1995). Catalogue of the vascular plants in Malaya. Garden's Bulletin Singapore (Vol. 47, pp. 347-757). Singapore Botanic Gardens 
[12] Nasir, A. F. A, Nordin, A. R. M., Nashriyah, M \& Rasid, M. A (2014) Automatic Identification of Ficus deltoidea Jack (Moraceae) Varieties Based on Leaf. Modern Applied Science, 8, 121-131.

[13] Larson, R. A. (1988) The antioxidants of higher plants. Phytochemistry, 4, 969-978.

[14] Liang, Y.Z. , Xie, P. S. \& Chan, K. (2004) Quality control of herbal medicines. Journal of Chromatography B, 812: 53-70..

[15] FDA Guidance for Industry (2000) - Botanical Drug Products (Draft Guidance), US Food and Drug Administration, Rockville, 4.

[16] European Medicines Agency (2001) Note for Guidance on Quality of Herbal Medicinal Products, London, 6.

[17] Bhutani, K. K. (2000) Finger-Printing of Ayurvedic Drugs, The Eastern Pharmacist, 21-26.

[18] Syazwani, D., Sharifah Ruzaina S. A. \& Ahmad, R. (2009) Antioxidant and radical scavenging activities of methanol and water extracts of Ficus deltoidea var. angustifolia. Malaysian Natural Product International Seminar (MNPIS) 2009 in Program Book and Compilation of Abstracts, 23-24 November 2009, M.S Garden Hotel, Kuantan, pg. 139.

[19] Choi, Y. H, Norhaniza, A. \& Saiful Anuar, K. Antioxidant activities and cytoctoxic effect of Ficus deltoidea. Malaysian Natural Product International Seminar (MNPIS) 2009 in Program Book and Compilation of Abstracts, 23-24 November 2009, M.S Garden Hotel, Kuantan, pg. 183, 2009.

[20] Zunoliza, A., Khalid, H., Zhari, I., Rasadah, M. A., Mazura, P., Fadzureena, J. \& Rohana, S. (2009) Evaluation of extracts of leaf of three Ficus deltoidea varieties for antioxidant activities and secondary metabolites. Pharmacognosy Research, 1(4), 216-223.

[21] Hakiman, M. \& Maziah, M. (2009) Non-ezymatic and enzymatic antioxidant activities in aqueous extract of different Ficus deltoidea accessions. Journal of Medicinal Plants, 3, 120-131.

[22] Omar, M. H., Mullen, W. \& Crozier, A. (2011) Identification of proanthocyanidin dimers and trimers, flavone C-glycosides, and antioxidants in Ficus deltoidea, a malaysian herbal tea," Journal of Agricultural and Food Chemistry, 59(4),1363-1369.

[23] Zunoliza, A., Zhari, I. \& Rasadah, M. A. (2010) Angiotensin-Converting Enzyme (ACE) Inhibitor from Ficus deltoidea Jack for Hypertension. Malaysian Journal of Pharmaceutical Sciences, 122.

[24] Nadiah, R., Aidiahmad, D., Mohd Zaini, A. \& Zhari, I. (2010) Methanol extracts of Ficus deltoidea leaves reduce contraction and enhance relaxation in isolated spontaneously hypertensive rat aortic rings. Malaysian Journal of Pharmaceutical Sciences, 61.

[25] Hasni, M., Azlina, A. A. \& Norhaniza, A. (2009) Potential Activity Compounds from Ficus deltoidea Fruit Aqueous Extract. Malaysian Natural Product International Seminar (MNPIS) 2009 in Program Book and Compilation of Abstracts, 23-24 November 2009, M.S Garden Hotel, Kuantan, pg. 135.

[26] Zainah, A, Muhajir, H., Amin, I. \& Shafii, K. Effect of Ficus deltoidea Aqueous extract on Blood Glucose Level in Normal and Mild Diabetic Rats. Jurnal Sains Kesihatan Malaysia, 5 (2), pp 9-16, 2007.

[27] Zainah, A., Shafii, K., Amin, I. \& Muhajir, H. (2010) Inhibitory Properties of Ficus deltoidea on $\alpha$ glucosidase activity. Research Journal of Medicinal Plant, 4(2), 61-75.

[28] Zainah, A., Amin, I., Shafii, K., Muhammad Hanaffi, M. M. \& Muhajir, H. (2011) Antihyperglycemic activity of Ficus deltoidea ethanolic extract in normal rats. Sains Malaysiana, 40, 489-495.

[29] Draman, S., Aris, M. A. M., Razman, A. et al. (2012) Mas cotek (Ficus deltoidea): a possible supplement for type II diabetes: (a pilot study)," Pertanika Journal of Tropical Agricultural Science, 35(1), 93-102.

[30] Kalman, D. S., Schwartz, H. I., Feldman, S. \& Krieger, D. R. (2013) Efficacy and safety of Elaeis guineensis and Ficus deltoidea leaf extracts in adults with pre-diabetes," Nutrition Journal, 12(1)36.

[31] Zakaria, Z. A., Hussain, M. K., Mohamad, A. S., Abdullah, F. C., \& Sulaiman, M. R. (2012) Antiinflammatory activity of the aqueous extract of Ficus deltoidea," Biological Research for Nursing, 14(1), 90-97.

[32] Oh, M. J., Abdul Hamid, M., Ngadiran, S., Seo, Y. K., Sarmidi, M. R., \& Park, C. S. (2011) Ficus deltoidea (Mas cotek) extract exerted anti-melanogenic activity by preventing tyrosinase activity in vitro and by suppressing tyrosinase gene expression in B16F1 melanoma cells. Archives of Dermatological Research, 303(3), 161-170.

[33] Hasham, R., Choi, H. K., Sarmidi, M. R., \& Park, C. S. (2013) Protective effects of a Ficus deltoidea (Mas cotek) extract against UVB-induced photoageing in skin cells. Biotechnology and Bioprocess Engineering, 18(1), 185-193. 
[34] Zahra, M. A. S. F., Mahmood, A. A., Hapipah, M. A., Suzita, M. N. \& Salmah, I. (2009) Antiulcerogenic activity of aqueous extract of Ficus deltoidea against ethanol-induced gastric mucosal injury in rats. Research Journal of Medical Sciences, 3(2),42-46.

[35] Abdulla, M. A., Abdul-Aziz Ahmed, K., Abu-Luhoom, F. M. \& Muhanid, M. (2010) Role of Ficus deltoidea extract in the enhancement of wound healing in experimental rats. Biomedical Research, 21(3), 241-245.

[36] Uyub, A. M., Nwachukwu, I. N., Azlan, A. A., \& Fariza, S. S. (2010) Invitro antibacterial activity and cytotoxicity of selected medicinal plant extracts from Penang island Malaysia on metronidazoleresistanthelicobacter pylori and some pathogenic bacteria," Ethnobotany Research and Applications, 8, 95-106.

[37] Samah, O.A., Zaidi, N. T. A. \& Sule, A. B. (2012) Antimicrobial activity of Ficus deltoidea Jack (Mas Cotek). Pakistan Journal of Pharmaceutical Sciences, 25(3), 675-678.

[38] Akhir, N. A. M., Chua, L. S., Majid, F. A. A., Sarmidi, M. R. 2011. Cytotoxicity of aqueous and ethanolic extracts of Ficus deltoidea on human ovarian carcinoma cell line. British Journal of Medicine and Medical Reasearch, 1(4), 397-409.

[39] Farsi, E., Shafaei, A., Hor, S. Y. et al. (2013) Genotoxicity and acute and subchronic toxicity studies of a standardized methanolic extract of Ficus deltoidea leaves. Clinics, 68(6), 865-875.

[40] Mohd Lip. J., Nazrul Hisham, D., Arif Zaidi, J. et al. (2009) Isolation and identification of moretenol from Ficus deltoidea leaves. Journal of Tropical Agriculture and Food Science, 37, 195-201.

[41] Choo, C. Y., Sulong, N. Y., Man, F. \& Wong, T. W. (2012) Vitexin and isovitexin from the Leaves of Ficus deltoidea with in vivo a-glucosidase inhibition. Journal of Ethnopharmacology, 142(3), 776-81.

[42] Prabhakar, M. C., Hassina ,B., Kumar, I., Shansi, M. A. \& Khan, M. S.Y. (1981) Pharmacological investigations on vitexin. Planta Medica, 43, 396-403.

[43] Agnese, A. M, Peres, C., Cabrera, J. L. (2001) Adesmia aegiceras: antimicrobial activity and chemical study. Phytomedicine, 389-394.

[44] Picerno, P., Mencherini, T., Lauro, M. R., Barbato, F. \& Aquino, R. (2003) Phenolic constituents and antioxidant properties of Xanthosoma violaceum leaves. Journal of Agriculture and Food Chemistry, 22, 6423-6428.

[45] Yao, Y., Cheng, X., Wang L., Wang, S. \& Ren, G. (2011) A determination of $\alpha$-glucosidase inhibitors from Azuki beans (Vigna angularis). International Journal of Molecular Sciences, 12, 6445-6541. 